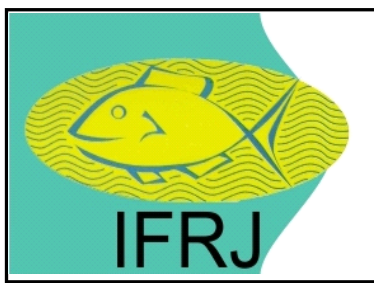

Available online at: http://ejournal-balitbang.kkp.go.id/index.php/ifrj

e-mail:ifrj.puslitbangkan@gmail.com

INDONESIAN FISHERIES RESEARCHJOURNAL

Volume 24 Nomor 2 December 2018

p-ISSN: 0853-8980, e-ISSN: 2502-6569

Accreditation Number RISTEKDIKTI: 21/E/KPT/2018

http://dx.doi.org/10.15578/ifrj.23.2.2017.125-131

\title{
POPULATION DYNAMICS OF MALAYAN LEAF FISH (Pristolepisgrooti Blkr.) IN RANAU LAKE, SOUTH SUMATERA
}

\author{
Sevi Sawestri ${ }^{* 1}$, Subagdja1 and Dina Muthmainnah ${ }^{1}$ \\ ${ }^{1}$ Research Institute for Inland Fisheries and Fisheries Extension, Jl. Gubernur H.A. Bastari No. 08. Palembang-Indonesia \\ Received; February 07-2018 Received in revised from August 28-2018; Accepted September 17-2018
}

\begin{abstract}
The Malayan leaf fish or locally named as kepor (Pristolepis grooti) is one of important biotic components in Ranau Lake ecosystems. This study aimed to estimate population dynamic and exploitation rate by growth parameters and fishing mortality rates of kepor in Ranau Lake, South Sumatera. The population parameters are estimated based on length frequency data which were collected in March to October 2013. Growth parameters and fishing mortality rates were calculated using FiSAT software package. The results showed that kepor's growth was negative allometric, which tended to gain length faster than weight. Kepor population was dominated (42\%) by individual length of 10.0 to $11.0 \mathrm{~cm}$. Predicted length infinity $\left(L_{\infty}\right)$ was $17.28 \mathrm{~cm}$ with high value of growth rates $(\mathrm{K})$ of 1.4 year $^{-1}$. The natural mortality rate $(\mathrm{M})$ is 2.57 year $^{-1}$, the fishing mortality rate $(F)$ is 5.36 year $^{-1}$ and total mortality rate $(Z)$ is 7.93 year $^{-1}$. The exploitation rate of Malayan leaf fish in Ranau Lake $\left(E=0.68\right.$ year $\left.^{-1}\right)$ has passed the optimum score.
\end{abstract}

\section{Keywords: Pristolepis grooti; population; growth; exploitation rate; Ranau Lake}

\section{INTRODUCTION}

The Malayan leaf fish is classified by Kottelat et al. (1993) as Actinopterygii (ray-finned fishes), order Perciformes (Perch-likes), family Pristolepididae, genus Pristolepis, Pristolepis grooti. The local name of this fish is kepor (Sumatera) or kapar (Borneo). Geographically, the species is found mostly in Mekong and Chao Phraya basins, Malay Peninsula, Sumatera and Borneo. The natural habitat of kepor is shallow forest pools, forest streams, swamps, bogs, and larger water bodies in cluding lakes and reservoirs (Kottelat et al., 1993). Kepor is potentially important for ornamental fisheries because of its body sharp and coloration (Anna-Mercy et al., 2003). This fish has relatively low price, at around IDR 5,000 to 15,000 per kilogram depending on the size. Usually, it is sold in six to seven individuals per bundle (Makmur, 2009).

Ranau Lake is the second largest lake in Sumatera after Toba Lake. It is located in South Ogan Komering Ulu-South Sumatera and West Lampung. The lake covers an area of about 12,800 ha with $16 \mathrm{~km}$ long and $8 \mathrm{~km}$ wide. The altitude is about $540 \mathrm{~m}$ above sea level. It is in habited by several species of freshwater fish including kepor. Fishing activity occurs all year round and is mostly operated using cast net and gill net with mesh size of 1-2 inch.
Knowledge of the fishery activities of Ranau Lake fish species still scientifically needs to be explored, as previously observed by Aida (2009), Makmur et al. (2014), Muthmainnah et al. (2014), and Makmur et al. (2017). However, observation on the growth of kepor in Ranau Lake has not been done. Providing information regarding population dynamics, particularly the estimate growth parameters and fishing mortality rates, is one of the important aspects to describe the existing fishing pressures. The results are expected to contribute in developing baseline information for future fisheries development and its management. Analysis of growth curve is essentials to provide adequate information for fish production (Effendie, 2002) and fundamental for sustainable and responsible fisheries management (Lagler, 1972). The definition of growth in fisheries is changing dimensions (in length, weight, volume, number, and size) per unit time, both individual and community (Effendie, 2002). Growth is one of biological indicator for a current state of individual, population, and environment (Moyle \& Cech, 1996).

The objectives of this work are to estimate population dynamic and exploitation rate based on growth parameters and fishing mortality rates of Malayan leaf fish (Pristolepis grooti Blkr.) in Ranau 
Lake, South Sumatera. This information is needed to ensure the sustainability of Malayan leaf fish of Ranau Lake.

\section{MATERIALS AND METHODS}

Recognizing basic parameters of dynamic fishing pressures to kepor species is needed to explore. Standard data acquisition for tropical fisheries was applied for the species as a data base for length based fish stock assessment following Sparre \& Venema (1999). Fish samples were measured in March to October 2013 in Banding Agung and Talang Teluk
Villages of Ranau Lake in South Sumatera Province, Indonesia (Figure 1). Fish samples (Figure 2) were collected based on two types of fishing gears: cast net and gillnet. Fish size was measured to the nearest $\mathrm{mm}$ for total length and the nearest gram for weight. The samples then were preserved in $10 \%$ formalin. Fish was identified by comparing morphometric and meristic features to reference guideline developed by Kottelat et al. (1993) and Weber \& de Beaufort (1936). Growth parameters and fishing mortality rates were calculated using FiSAT II software package of FAOICLARM Stock Assessment Tool (Gayanilo et al., 1995).

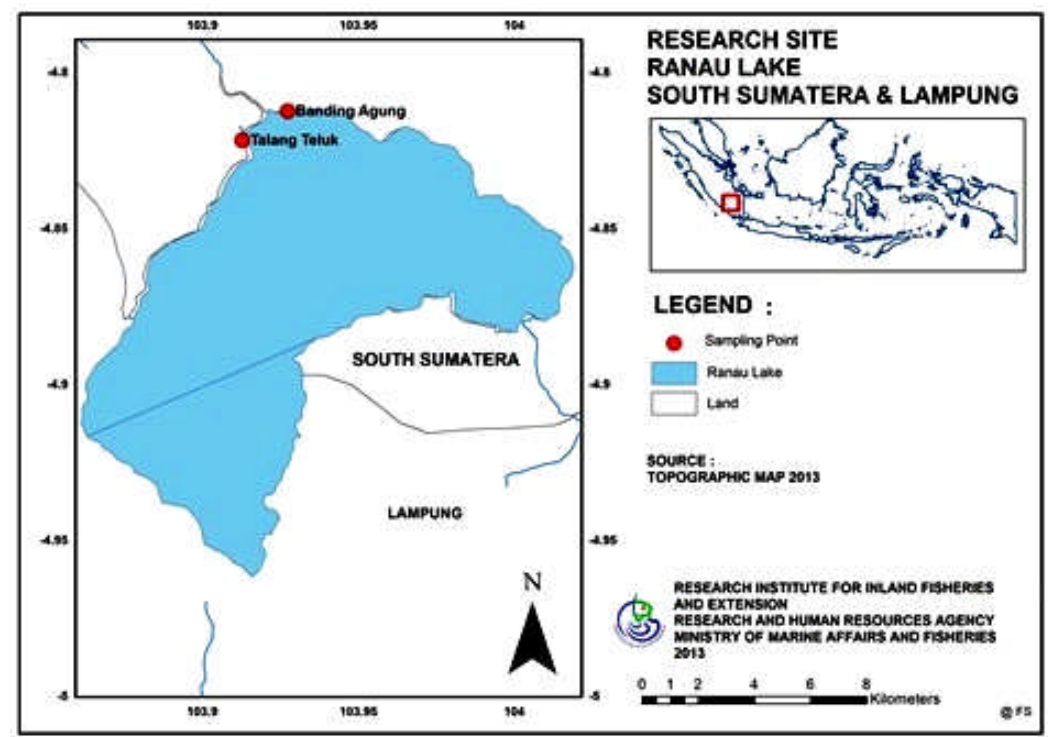

Figure 1. Map of research site.

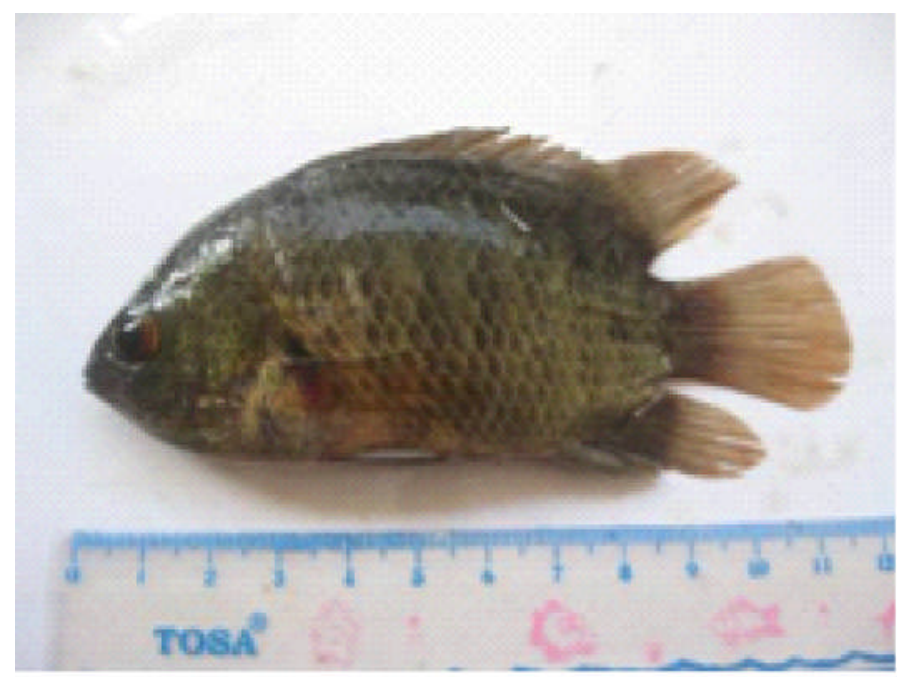

Figure 2. The Malayan leaf fish (Pristolepis grooti).

\section{Length-Weight Relationship}

The length-weight relationship is intended for measuring the variation of expected weight at certain length of individual fish or relevant group of individuals as an indication of healthy body or gonad development. The curve of relationship of length and weight was calculated using the following equation (Effendie, 1979): 
$W=a L^{b}$

Where;

$W=$ weight of fish (gram)

$L=$ length of fish $(\mathrm{cm})$

$a=$ a constant (intercept),

$b=$ a constant (slope of regression line).

The value of exponent $b$ provides information on fish growth. The growth characteristic was determined as:

a. Isometric growth pattern, indicated by $b=3$. Isometric growth implies that there is no change of body shape as an organism grows.

b. Allometric growth pattern, indicated by $b \neq 3$. Allometric growth involves changing proportion of body shape as an organism grows. Negative allometry $(b<3)$ occurs when the fish gets relatively thinner as it grows and positive allometric $(b>3)$ indicates heavier weight for a particular length.

The value of exponent $b$ was tested using a standard t-test of $95 \%$ confidence level ( $\alpha=0.05$ ) using the null hypothesis of the isometric growth of:

a. $H_{0}: b=3$ (isometric growth pattern) and

b. $H_{1}: b \neq 3$ (allometric growth pattern)

\section{Estimation of Growth Parameters}

The age and growth curves were estimated using the growth coefficient $(K)$ of the Von Bertalanffy model following Sparre \& Venema (1999):

$L_{t}=L \infty\left(1-e^{-K(t-t 0)}\right)$

Where:

$L_{t}=$ length $(L)$ over time $(t)$

$L_{\infty}=L$ infinity is the mean maximum length $(t=$ infinity)

$K=a$ rate constant with units of reciprocal time (year $\left.t^{1}\right)$

$t_{0}=$ the mean length at birth $(t=0)$

The estimation of asymptote total length $\left(L_{\infty}\right)$ and growth coefficient $(K)$, were calculated using Elefan1 in FISAT II computer program package. An estimated value for $t_{0}$ was following Pauly (1984) equation in Sparre \&Venema (1999): $\log -\left(t_{0}\right)=-0.3922-0.2752 \log L_{\infty}-1.038 \log$

$K$

The estimate of natural mortality was described following Pauly (1980):

$\log (M)=-0.0066-0.279^{*} \log L_{\infty}+0.6543^{*} \log K$ $+0.4634^{*} \log \mathrm{T}$

(4)

where:

$L_{\infty}=$ asymptotic total length,

$K=$ growth coefficient,

$T=$ mean environmental temperature in Ranau Lake $\left(27.5^{\circ} \mathrm{C}\right)$.

The total mortality $(Z)$ of fish, comprises fishing mortality and natural mortality, is an important biological parameter for stock assessments. This parameter is generally estimated using the lengthconverted catch method (LCCM) (Pauly, 1983). Z was assumed to be constant for all age classes. Fishing mortality coefficient $(F)$ was estimated by subtracting natural mortality $(M)$ from total mortality $(Z)$ as in the following equation:

$F=(Z-M)$

The rate of exploitation $(E)$ is calculated using the equation of Pauly (1980).

$E=F / Z$

\section{RESULTS AND DISCUSSION \\ Results}

\section{Size Distribution and Length-Weight Relationship}

The monthly length and weight data showed that the size of fish caught were relatively varied (Table 1). The longest fish could be captured in August, while the smallest fish were caught in June. Its weight followed the length of the fish.

A total of 1,469 kepor from Ranau Lake were analyzed. The total length of fish ranged from 60.0 $\mathrm{mm}$ to $160.0 \mathrm{~mm}$. They were grouped into ten classes of total length frequency. 
Table 1. Monthly length and weight of Malayan leaf fish in Ranau Lake

\begin{tabular}{llcllllllll}
\hline \multirow{2}{*}{ No } & \multirow{2}{*}{ Period of sampling } & \multirow{2}{*}{$\mathbf{N}$} & \multicolumn{3}{c}{ Total Length (cm) } & \multicolumn{4}{c}{ Weight (g) } \\
& & & Max & Min & $\mathbf{X}$ & std & Max & Min & Y & std \\
\hline 1 & March & 180 & 13 & 8.4 & 10.42 & 0.75 & 46.12 & 13.57 & 24.35 & 5.11 \\
2 & April & 196 & 15.5 & 8 & 10.40 & 1.02 & 77.28 & 8.26 & 25.55 & 7.77 \\
3 & May & 221 & 15.5 & 7.3 & 10.87 & 1.64 & 89.79 & 13.51 & 29.99 & 15.7 \\
4 & June & 175 & 14.2 & 6 & 10.88 & 1.17 & 65.47 & 4.57 & 28.67 & 10.3 \\
5 & July & 142 & 15 & 8.5 & 10.17 & 1.23 & 59.12 & 12.77 & 16.34 & 8.38 \\
6 & August & 193 & 16 & 6.8 & 10.84 & 1.48 & 93.8 & 7.01 & 28.64 & 14.2 \\
7 & September & 206 & 14 & 8.3 & 10.42 & 0.89 & 58.84 & 13.47 & 25.83 & 7.41 \\
8 & October & 156 & 15.7 & 7.5 & 10.39 & 1.15 & 87.04 & 9.16 & 25.04 & 10.1 \\
\hline
\end{tabular}

Remarks: $X$ = average length $(\mathrm{cm})$

$\mathrm{Y}=$ average weight $(\mathrm{g})$

std $=$ standard deviation

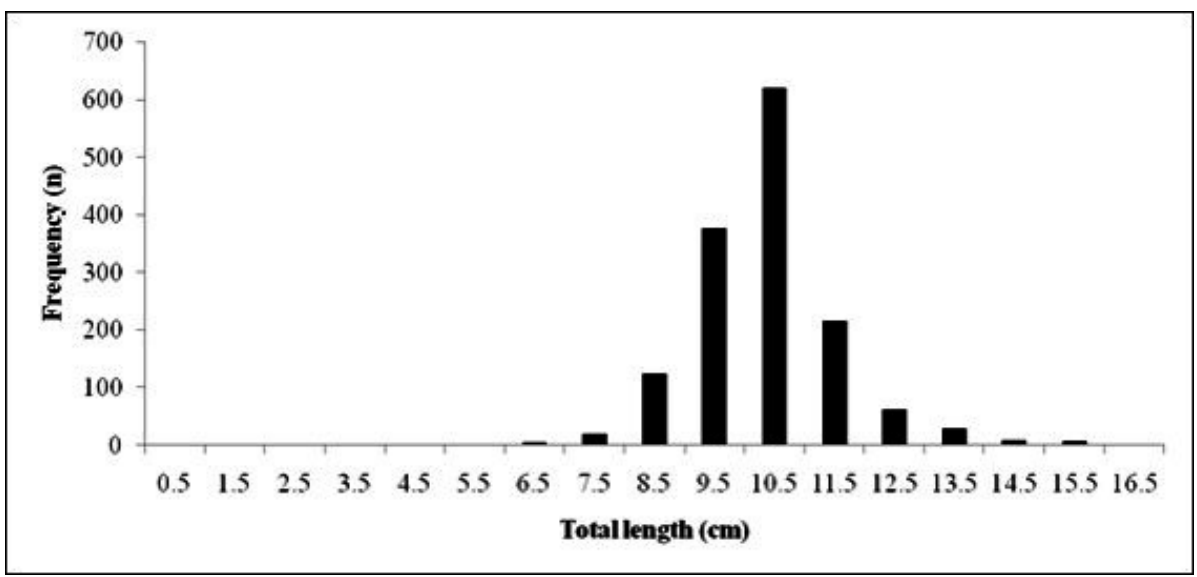

Figure 3. Total length frequency distribution of malayan leaf fish (Pristolepis grooti) in Ranau Lake.

Figure 3 shows that total length frequency of kepor tended to be normal distribution with length modus of $105.0 \mathrm{~mm}$ and was dominated (42\%) by $100-110 \mathrm{~mm}$ length distribution. The equation of length-weight relationship (LWR) of kepor was $W=0.028 L^{2.876}$, where the coefficient of determination $\left(R^{2}\right)$ was 0.886 (Figure
4). The coefficient of determination value indicates that the lenght and weight have a close relationship. The calculated $b$ value was 2.876 , which showed that fish has negative allometric growth pattern. Ranau's kepor has faster growth rate of the body length compared to the weight

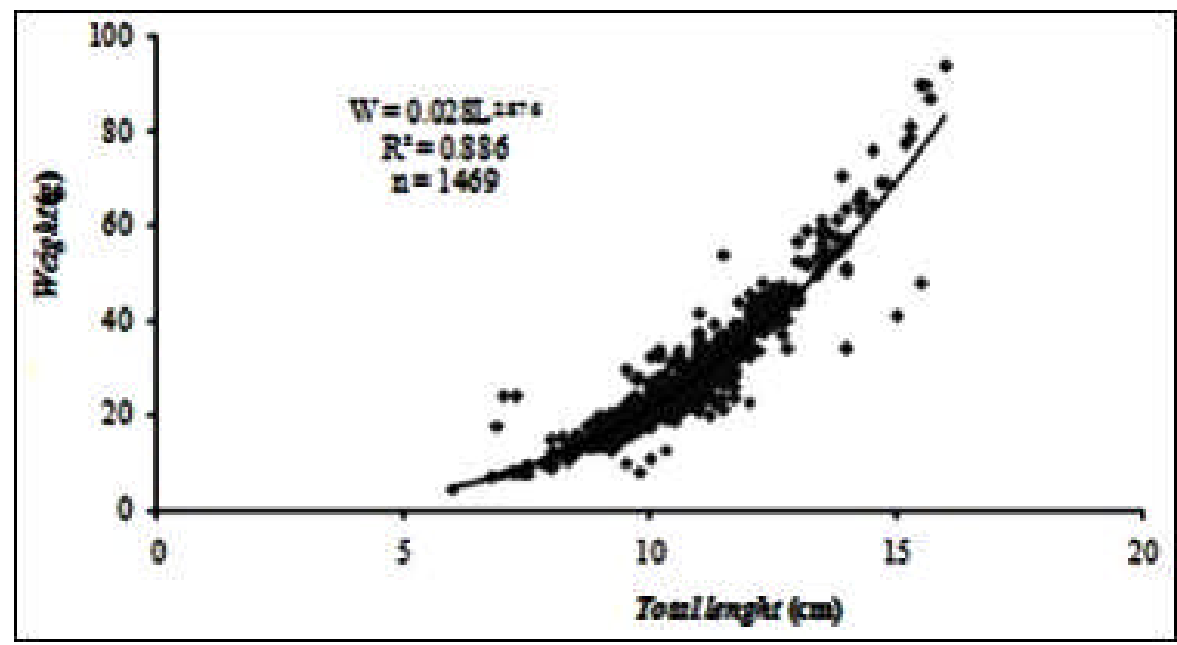

Figure 4. Length-weight relationship of Malayan leaf fish (Pristolepis grooti) in Ranau Lake, 2013. 


\section{Growth and Mortality Parameters}

The result analyses of growth parameters estimated by ELEFAN 1 showed that kepor in Ranau
Lake has a $K$ value of 1.4 year $^{-1}$, and the value for $L$ infinity is $172.8 \mathrm{~mm}$ (Figure 5). Figure 6 showed the distribution of total length and the growth of Malayan leaf fish (Pristolepis grooti) in Ranau Lake.

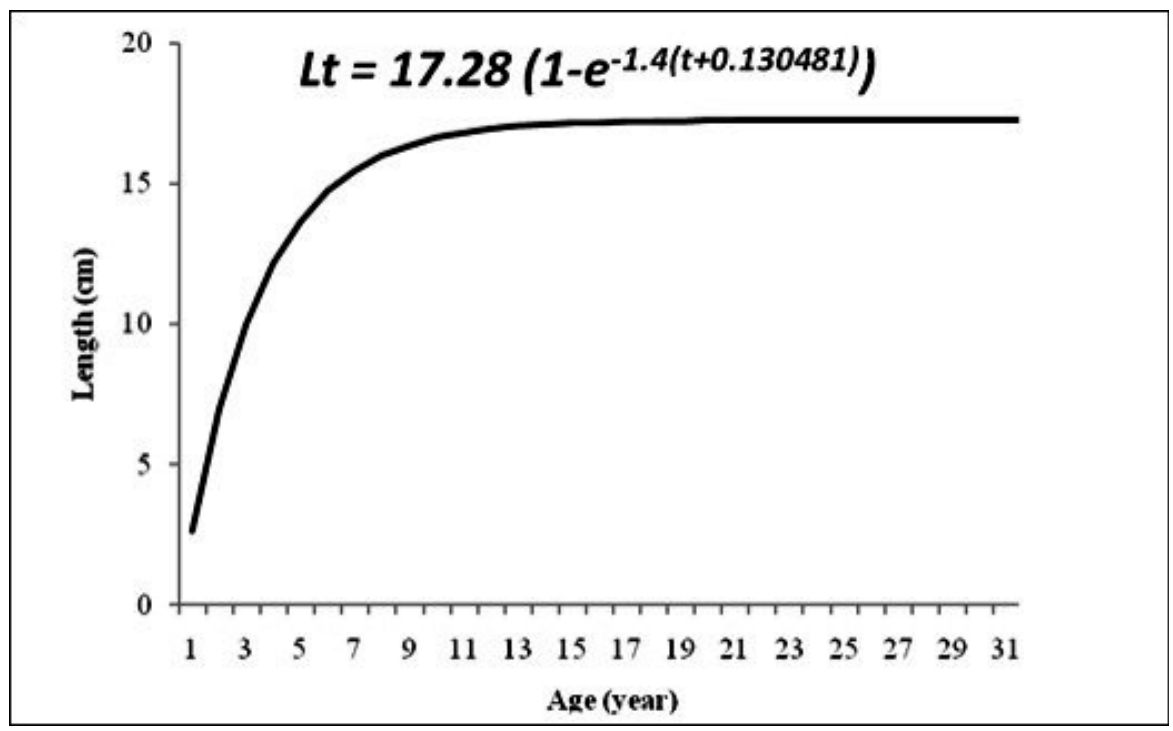

Figure 5. Von Bertalanffy growth function curve of Malayan leaf fish (Pristolepis grooti) in Ranau Lake.

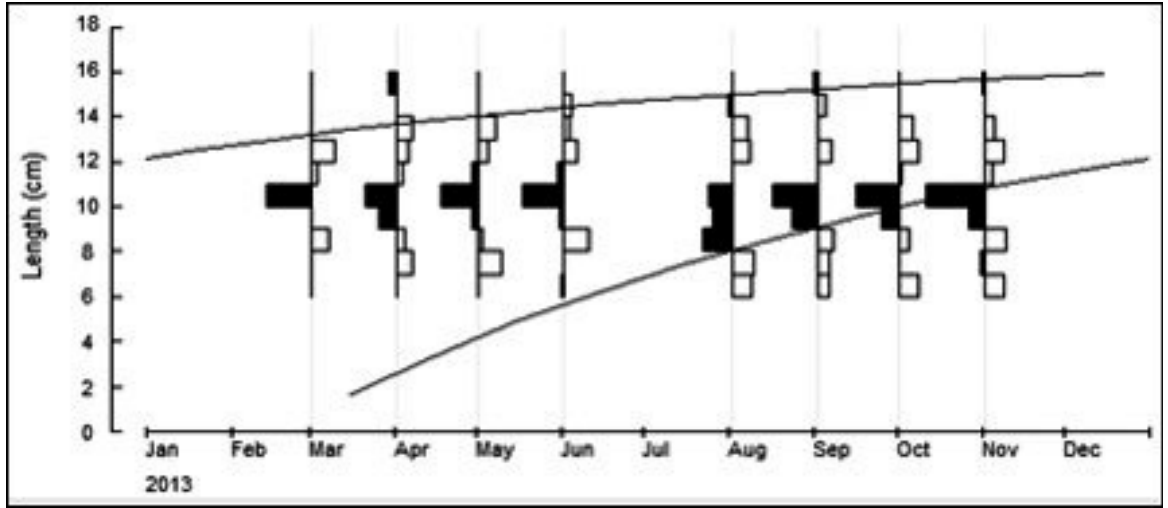

Figure 6. Distribution of total length and growth of Malayan leaf fish (Pristolepis grooti) in Ranau Lake.

Nobles et al. (2015) stated that understanding how mortality and fertility are linked is essential to study population dynamics. In this case, natural mortality $(M)$ of kepor was 2.57 year $^{-1}$, fishing mortality $(F)$ was 5.36 year $^{-1}$, and total mortality $(Z)$ was 7.93 . The fishing and natural mortality are combined to get a total mortality $(Z)$. The rate of exploitation $(E)$ was calculated from $F$ and $Z$ and the result was 0.68 , indicated that exploitation rate of Malayan leaf fish in Ranau Lake has passed the optimum score $(E=0.50)$.

\section{Discussion}

The Malayan leaf fish, kepor, inhibited in Ranau Lake has a small size. Aida (2009) stated that kepor caught in Ranau Lake in 2009 had length size between $6.70-20.20 \mathrm{~cm}$, dominated by $9.10-11.30 \mathrm{~cm}$. Asriansyah (2008) noted that total length of kepor in
Musi River in 2008 had size range of $5.0-14.8 \mathrm{~cm}$. Parenti \& Lim (2005) also reported that total length of Malayan leaf fish in Kapit, Serawak, reach $15 \mathrm{~cm}$ only. Unfortunately, the authors did not write the information of fishing gears they used to catch the fish. However, the variation of kepor's total length was caused by different types and mesh sizes of fishing gears used for catching the fish. The characteristics of fish can complicate size selection patterns, including seasonal migration timing of components of fish stocks that differ in age and size, and temporal variation in fishing schedule and intensity (Kendall et al., 2009).

The calculated $b$ value in this study is 2.876 . This showed that kepor has negative allometric growth pattern. The fish tended to gain length faster than weight. This result was similar with Aida (2009) who reported the calculated $b$ of Malayan leaf fish was 
2.8349. Meanwhile, Asriansyah (2008) and Ernawati et al. (2009) reported that the Malayan leaf fish of Musi River had positive allometric growth pattern. Rahardjo et al. (2011) stated that such variations in $b$ value might depend upon various factors like number of specimen examined (more samples, more accurate results), condition of places of sampling, and sampling season. Even though the change of values depends primarily on the shape and fatness of the species, it can be affected by various factors like temperature, salinity, food (quantity, quality, and size), and sex and stage of maturity (Effendie, 2002). The length-weight relationship of the fish is also affected by a number of other factors, including gonad maturity, sex, diet, stomach fullness, health, and preservation techniques as well as season and habitat. However, these factors were not accounted for the present study.

The length infinity $\left(L_{\infty}\right)$ of kepor showed that population of fish would be reached if they grow indefinitely. Growth coefficient $(K)$ expresses the rate (one per-year) at which the length infinity could be approached. Growth coefficient $(K)$ showed how long the fish will grow to reach length and weight infinity (Sparre \& Venema, 1999).

The length infinity and growth coefficient of Ranau's kepor are indifferent from the ones in previous studies. The length infinity of Ranau's kepor is smaller than Thailand's kepor. The length infinity $P$. fasciata in Phayao Lake, Thailand, has $21 \mathrm{~cm}$ and $32 \mathrm{~cm}$ in Rajjaprabha Lake. Jintanugool \& Philip on Fishbase (2011) reported that $P$. fasciata in Phayao Lake, Thailand, 0.94 year $^{-1}$ of growth coefficient. Moreau and Sricharoendham (1999) also reported that $P$. fasciata in Rajjaprabha Lake, Thailand, has 0.44 year $^{-1}$, respectively. The growth rate of $P$. grooti in Ranau Lake was longer than another estimate of $P$. fasciata in Thailand.

The growth coefficient $(K)$ of kepor showed the value was greater than other studies. The greater of this value indicates that the fish growth rate to achieve the maximum size is faster. According to Wudji et al. (2012), growth parameter of fish has relationship to water quality.

Mortality is an important aspect of population biology since it provides information about shifting in the population structures. Mortality can be caused by fishing activity (called fishing mortality) or by natural action (natural mortality). The decrease in numbers of a year class of fish by death through time is usually expressed by means of exponential rates (Pauly, 1983). The three commonly defined rates according to Pauly (1983) are: 1) Natural mortality includes all deaths due to natural causes like predation, diseases and old age;2) Fishing mortality rate is death of fish caused by fishing mortality, 3 ) Total mortality rate is the combination of natural mortality and fishing mortality.

Fishing mortality rate $(F)$ has shown by increasing of fishing pressure on fish stocks in the waters (Suman \& Boer 2005 in Damora \& Wagiyo 2012). Exploitation rate allows for determining whether a stock is overfished or not based on the assumption that the optimal value of $E$ is 0.5 (Pauly, 1983). Based on the exploitation rate $(E)$ of kepor in this study $(0.68)$, it showed that the utilization of the fish was intensively exploited and tended to overfished. Although kepor is not the main target fish but if this condition continues without any efforts to organize the utilization of this fish, it indicatesthat the fish resources would be threatened in the long term.

\section{CONCLUSION}

The negative allometric ( $b$ value $=2.876)$ growth of Malayan leaf fish informed a faster growth rate of the body length compared to the weight. This study indicated that the characteristic of fish is in high growth rates $\left(K=1.4\right.$ year $\left.^{-1}\right)$ and high natural mortality $(M=$ 2.57 year $\left.^{-1}\right)$ and total mortality $(Z=7.93)$ while fishing mortality $(F)$ was 5.36 year $^{-1}$. The exploitation rate of Malayan leaf fish in Ranau Lake $\left(E=0.68\right.$ year $\left.^{-1}\right)$ has passed the optimum score.

\section{ACKNOWLEDGEMENT}

The authors thank to Mr. Dwi Atminarso and Mr. Makri for their assistance during the course of sampling. Furthermore, we thank to the Ministry of Marine Affairs and Fisheries Republic of Indonesia for funding support throughout the Research Institute for Inland Fisheries in fiscal year of 2013.

\section{REFERENCES}

Aida, S.N. (2009.) Growth rate of malayan leaf fish (Pristolepis grooti) in Ranau Lake South Sumatera. Proceeding of National Conference Indonesia Inland Water VI (in Indonesia). Palembang: Research Institute for Inland Fisheries. BP 119-125. 18 November 2009.

Anna Mercy, T.V., Jacob, E., \& Thomas, R.K. (2003). Studies on the reproductive behavior of the Common Catopra, Pristolepis marginata Jerdon (Nandidae-Perciformes) under captive condition ( $\mathrm{p}$. 682). College of Fisheries, Kerala Agricultural University, Panangad, Cochin. India. 
Asriansyah, A. (2008). Food habit of sepatung (Pristolepis grooti) in Musi Watershed, South Sumatera (in Indonesia). [Thesis]. Bogor: Bogor Agricutural University.

Damora, A., \& Wagiyo, K. (2012). Population parameter of Sadah (Valamugils peigleri) as indicator of estuaries resources utilization in Pemalang (in Indonesia). BAWAL 4(2), 91-94. http://dx.doi.org/10.15578/bawal.4.2.2012.91-96.

Effendie, M.I. (1979). Fisheries biology method (p. 112) (in Indonesia). Bogor: Yayasan Dewi Sri.

Effendie, M.I. (2002). Fisheries biology (in Indonesia). Yogyakarta: Yayasan Pustaka Nusantara.

Ernawati, Y., Aida, S.N., \& Juwaini, H.A. (2009). Reproduction biology of Sepatung, Pristelopis grootii Blkr. 1852 (Nandidae) in Musi River (in Indonesia). Jurnal Iktiologi Indonesia, 9(1), 13-24.

www. http://fishbase.pl/2011/01/pristolepis-fasciata. $23^{\text {rd }}$ February 2018.

Gayanilo, Jr. F.C., Sparre, P., \& Pauly, D. (1995). The FAO ICLARM stock assessment tools (FiSAT) User's guide (p. 126). FAO Computerized Information Series Fisheries. ICLARM Contribution, 1048.

Kottelat, M., Whitten, A.J., Kartikasari, S.N., \& S. Wirjoatmodjo. (1993). Freshwater fishes of Western Indonesia and Sulawesi (p. 221). Hongkong: Periplus Editions.

Lagler, K.F. (1972). Freshwater fishery biology. W. M. C. (p. 371-191). lowa: Brown Company Publisher Dubuque. 404 p.

Makmur, S. (2009). Malayan leaf fish (Pristolepis fasciata Blkr) in Ranau Lake (in Indonesia). Have you known. (Ed.) Desember 2009 No. 1. www.kkp.go.id.

Makmur, S., Arfiati, D., Bintoro, G., \& Ekawati, A.W. (2014). Morphological, meristic characteristics and mtDNA analysis of Hampala Fish (Hampala macrolepidota Kuhl \& Van Hasselt 1823) from Ranau Lake, Indonesia. Journal of Biodiversity and Environmental Sciences (JBES). 5(2), 447-455.

Makmur, S., Muthmainnah, D., \& Subagdja. (2017). Management of Hampal Barb (Hampala macrolepidota Kuhl \& van Hasselt 1823) in Ranau Lake, South Sumatera and Lampung (in Indonesia). Indonesian Policy Fisheries Journal. 9(2), 61-70.
Moreau, J., \& Sricharoendham, B. (1999). Growth mortality and recruitment of fish populations in Asian man made Lake Rajjaprabha Reservoir (Thailand) as assessed by length frequency analysis. Asian Fish. Sci. 12 (3), 277-288.

Moyle, P.B., \& Cech, J.J. (1996). Fishes an Introduction to Ichthyology (p. 341). New Jersey: Prentice Hall.

Muthmainnah, D., Makri., Subagdja., Atminarso, D., Sawetri, S., \& Makmur, S. (2014). Selectivity and effectiveness of different gillnet mesh sizes used in Ranau Lake of Sumatera. Journal of Biodiversity and Environmental Sciences (JBES). 5(5), 82-89.

Nobles, J., Frankenberg, E., \& Thomas, D. (2015). The effects of mortality on fertility: population dynamics after a natural disaster. Demography. 2015 Feb: 52(1), 15-38. Doi. 10.1007/s13524-0140362-1. National Center for Biotechnology Information, U.S. National Library of Medicine 8600 Rockville Pike, Bethesda MD, 20894 USA.

Parenti, L.R., \& Lim, K.K.P. (2005). Fishes of the Rajang Basin, Sarawak, Malaysia. The Raffles Bulletin of Zoology. 13, 175-208.

Pauly, D. (1980). A selection of simple methods for the assessment of tropical fish stocks (p. 54). FAO Fish. Circ. 729.

Pauly, D. (1983). Length-converted catch curves: a powerful tool for fisheries research in the tropics (part 1). ICLARM Fishbyte, 2, 9-13.

Rahardjo, M.F., Djadja, S.S., Ridwan, A., Sulistiono., \& Johannes, H. (2011). Iktiology (p. 394) (in Indonesia). Bandung: Lubuk Agung.

Sparre, P., \& Venema, S.C. (1999). Introduction to tropical fish stock assessment-Part 1: Manual ( $p$. 438). (in Indonesian). Jakarta: Research and Development Center of Fisheries.

Weber, M., \& de Beaufort, L.F. (1936). The fishes of the Indo-Australian Archipelago VII. Leiden: E.J. Brill.

Wudji, A., Suwarso., \& Wudianto. (2012). Several parameters of Lemuru population (Sardinella lemuru Bleeker, 1853) in Bali Strait (in Indonesia). BAWAL. 4(2), 83-89. DOI: http://dx.doi.org/ 10.15578/bawal.4.2.2012.83-89. 